\title{
SOYA MILK BASED EXTENDERS FOR CHILLED PRSERVATION OF HOLISTEIN BULL SEMEN AT $5^{\circ} \mathrm{C}$
}

\author{
E.M. EL-Seify ${ }^{1}$ I.M. Abd El-Razek ${ }^{* 2}$ and I.S. El-Shamaa ${ }^{* 2}$ \\ 1- Animal Production Research Institute, Agriculture Research Center, Ministry of Agriculture, Dokki, Egypt, \\ 2-Animal Production Department, Faculty of Agriculture, Kafr El-Sheikh University, Egypt \\ *Corresponding author E-mail: elshamaa2008@yahoo.com; ibrahimabdelrazek2006@yahoo.com
}

\section{SUMMARY}

Egg yolk (EY) based extenders have long been used for chilling and freezing bovine bull semen. Recently, several studies have shown that the use of EY involves hygienic risks and probable drawbacks on sperm integrity and subsequent fertility. Hence, several attempts were made to replace the traditional EY with some plant origin substitutes in the formulating bovine semen extenders. In this study, semen was collected once weekly by artificial vagina from five sexually mature Holstein bulls for 12 weeks to compare and evaluate the effect of replacement of the conventional Tris-egg yolk extender with different concentrations of soybean milk $(4,7,10$ and $13 \%)$. The quality of chilled semen after dilution and storage at $5^{\circ} \mathrm{C}$ for $0,24,48$ and $96 \mathrm{~h}$ was evaluated.

The results showed that the use of $7 \%$ soybean milk was the best compared to the other experimental concentrations. In addition, the use of $7 \%$ soybean milk extender tended to maintain sperm motility, viability, plasma membrane and acrosome integrity for a longer period of time than that of the other extenders tested. All soybean concentrations improved $(P \leq 0.05)$ sperm progressive motility; live sperm; acrosome and plasma membrane integrity at the different storage periods. Supplementing the extender with 13\% soybean milk had adverse effects on the semen parameters during cool storage.

It could be concluded that the inclusion of soybean milk to Holstein bull semen extender as a substitute to EY at the rate of $7 \%$ is favorable for better sanitation and preservation at $5^{\circ} \mathrm{C}$ of that semen.

\section{Keywords: Holstein bulls, semen, extender, soya bean milk, preservation}

\section{INTRODUCTION}

Modern dairy industry extensively depends upon semen preservation for artificial insemination (AI). Although, chilled semen has a relatively short shelf life, it is technically easier and cheaper than freezing one (Singh et al., 2012). Storage at $5^{\circ} \mathrm{C}$ is lowering the spermatozoa metabolic rate, thus, extending cell viability (Vishwanath and Hannon, 2000). Semen extenders must provide suitable media for longer survival of spermatozoa. Animal origin egg yolk based extenders are largely used in frozen and chilled semen preservation (Wall and Foote, 1999 and Stradaioli et al., 2007). Semen extenders may contain up to $20 \%$ egg yolk, however, their use involves hygienic risk; interference with fertility. The presence of fat globules of egg yolk in the extenders was also interferes in microscopic examination of diluted semen and makes the evaluation of sperm difficult (Singh et al., 2012). These circumstances require partial or complete replacement of egg yolk in semen extender with a non-animal origin substance such as soybean extracted milk (Ansari et al., 2013 and Rehman et al., 2014). According to Aires et al. (2003), soy-lecithin-based extender was found to be superior to egg yolk based extender for preserving bovine and ovine semen. Recently, ElKeraby et al. (2010) found that replacing EY with whole soybean milk increased sperm motility and decreased bacterial count in post-thawing bovine semen. In addition, several commercially available non-animal origin extenders such as Biociphos plus and Bioxcell (IMV, L'Aigle, France) are very potent substitutes to egg yolk-based extender. Like egg yolk, soybean contains a high amount of low density lipoprotein like lecithin which could successfully replace the fundamental yolk based extender for the preservation of semen (Rehman et al., 2014). These soybean milk based extenders showed better postthawing semen quality in different species over egg yolk-based extenders (Aires et al., 2003; Stradaioli et al., 2007; Forouzanfar et al., 2010 and El-Keraby et al., 2010 \& 2013).

The objective of this study was to compare and evaluate the effect of substitution of chicken egg yolk with different levels of soybean milk in semen extender on the quality of Holstein bull spermatozoa preserved at $5^{\circ} \mathrm{C}$ for four days.

\section{MATERIALS AND METHODS}

This study was carried out at the International Livestock Management Training Center (ILMTC) at Kafr El-Sheikh, Animal Production Research Institute, Ministry of Agriculture, Egypt; during the period from January to March 2014.

\section{Preparation of Soybean milk:}

An amount of 10 gram of soybean grains was washed, soaked in $100 \mathrm{ml}$ distilled water and boiled for $30 \mathrm{~min}$. Afterward, the water was discarded, the whole soybean grains washed again and finally cooled down with $50 \mathrm{ml}$ distilled water containing 
$0.25 \% \mathrm{NaHCo}_{3}$. Soybean grains were then grounded in a blender for $5 \mathrm{~min}$ and the slurry cooled. Soybean milk was extracted by filtration through a clean cotton cloth, centrifuged and boiled again for $10 \mathrm{~min}$. The slurry was allowed to cool down. Then, $0.25 \mathrm{gm}$ Lincospectin and $0.005 \mathrm{gm}$ Streptomycin $/ 100 \mathrm{ml}$ antibiotics were added to the slurry. After all, the soybean milk was ready for use.

\section{Semen collection and evaluation:}

Following sexual preparation, the semen was collected once weekly from five Holstein bulls (aged 3-4 years) for 12 weeks. All bulls were healthy and clinically free from external and internal parasites. Palpation of the testicles showed that they were typically normal. The testicular tone was glandular, almost equal in size and movable freely up and down within the scrotal pouches. Immediately after semen collection, ejaculates were held in water bath at $37^{\circ} \mathrm{C}$ until evaluated. Ejaculates of more than $70 \%$ motility were used by pooling to eliminate the effect of bull. On each collection day, fresh semen was split into five equal parts. The control group was extended by Tris-based egg yolk extender (TEY) consisted of $3.025 \mathrm{gm}$ Tris (hydroxymethyl amino methane), 1.675 gm citric acid, $0.75 \mathrm{gm}$ glucose, $20 \mathrm{ml}$ egg yolk, $0.005 \mathrm{gm}$ streptomycin and completed with bidistilled water up to $100 \mathrm{ml}$. The other four groups were extended with the same extender, but the whole egg yolk was replaced by $4,7,10$ and $13 \%$ soybean milk at the rate of $20 \times 10^{6}$ motile spermatozoa $/ \mathrm{ml}$. The extended semen was loaded in $0.25 \mathrm{ml}$ French straws using a semen filling machine. Diluted semen were gradually cooled down to $5^{\circ} \mathrm{C}$ in a refrigerator and stored for four days at the same temperature. At each period of semen storage (i.e., 0, 24, 48, 72 and $96 \mathrm{~h})$, the quality of semen was assessed.

\section{Semen evaluation:}

\section{Assessment of sperm motility and livability:}

A total of four straws from each extender were separately immersed in a water bath at $37^{\circ} \mathrm{C}$ for $10 \mathrm{~s}$. Sperm motility and livability were observed at 0,24 , 48, 72 and $96 \mathrm{~h}$ of storage every week using $5 \mu \mathrm{l}$ semen placed on pre-warmed glass slide and covered with a warm cover slip. For each sample, at least five microscopic fields were examined for $10 \mu \mathrm{l}$ semen sample at a magnification of X 400 using a phasecontrast inverted light microscope (CKX41; Olympus, Tokyo, Japan) with a warm stage maintained at $37{ }^{\circ} \mathrm{C}$. The mean of three successive evaluations at each period of semen storage was recorded as the final motility score. Sperm livability was determined after staining the semen with eosin negrosin mixture At least 200 spermatozoa were counted per slide. Absolute index of livability for each sample was calculated as described by Younis et al. (1999).

\section{Assessment of membrane and acrosome integrity:}

Membrane integrity was assessed using HypoOsmotic Swelling test (HOS) based on curled and swollen tail. The hypo-osmotic solution (150
mosm/L) was prepared by dissolving $0.735 \mathrm{~g}$ Sodium citrate dihydrate and $1.35 \mathrm{~g}$ fructose in $100 \mathrm{ml}$ distilled water. A one $\mathrm{ml}$ of hypo-osmotic solution was mixed with $0.1 \mathrm{ml}$ of semen and incubated at $37^{\circ}$ $\mathrm{C}$ for an hour. A drop of diluted semen was placed on a clean dry glass slide and covered by cover slip. A total of 100 spermatozoa were counted under a phase contrast microscope (400x magnifications). The percentage of spermatozoa positive to HOS test (having curled and swollen tail) was determined (Jeyendran et al., 1984 and Lodhi et al., 2008). Whereas, sperm acrosomal integrity was estimated using Giemsa stain (Watson, 1975) and the microscopic examination was carried out using oil immersion lens (x1000).

\section{Statistical analysis:}

The experimental data were statistically analyzed according to Snedecor and Cochran (1982) using SAS program (1999). Two way analysis of variance and Duncan's multiple range tests were done for the obtained data after angular transformation of percentages to their corresponding arc-sin values according the following model:

$\mathrm{Y}_{\mathrm{ijk}}=\mu+\mathrm{J}_{\mathrm{i}}+\mathrm{T}_{\mathrm{j}}+(\mathrm{J} * \mathrm{~T})_{\mathrm{ij}}+\mathrm{E}_{\mathrm{ijk}}$

Where, $\mathrm{Y}_{\mathrm{ijk}}=$ any observation, $\mu=$ overall mean, $\mathrm{J}_{\mathrm{i}}=$ extenders treatments $(\mathrm{i}=1,2,3, \ldots), \mathrm{T}_{\mathrm{j}}=$ time of storage $(\mathrm{j}=1,2,3, \ldots \ldots),\left(\mathrm{T}^{*} \mathrm{P}\right)_{\mathrm{ij}}=$ the interaction between Period of sampling and treatment, $\mathrm{E}_{\mathrm{ijk}}=$ experimental error. The significant differences among means were tested using Duncan's new multiple range tests, the level of statistical significance was set at $\mathrm{P}>0.05$.

\section{RESULTS AND DISCUSSION}

\section{Progressive motility:}

The mean values $( \pm \mathrm{SE})$ of progressive motility for five experimental extenders during storage at $5^{\circ} \mathrm{C}$ for $96 \mathrm{~h}$ were assessed and the results are shown in Table (1).

Sperm motility in the freshly diluted semen did not show any significant differences among the different extenders used. The first significant difference in sperm motility was detected with the advancement of storage time after 24 hours for $7 \%$ soya milk based extender $(\mathrm{P}<0.05)$. In the meantime, sperm progressive motility in extender with $13 \%$ soybean milk was significantly $(\mathrm{P}<0.05)$ lower than that of the control (TEY) at all storage periods except at $72 \mathrm{~h}$ of storage was not significant. With regard to the progressive motility of sperm, the use of $7 \%$ soya milk showed the best compared to the other experimental concentrations and times of storage. These finding are supported by that of Singh et al. (2012) in buffaloes, Akhter et al. (2010), El-Keraby et al. (2013) in buffalo frozen semen and El-Keraby et al. (2010) in bovine frozen semen who recorded an improvement in sperm motility parameters when buffalo and bovine semen was preserved in extender containing soybean milk in compared with that in tris-egg yolk extender. Also, El-keraby et al. (2010) 
concluded that replacing the traditional egg yolk with soybean milk in formulating bovine semen extender resulted in lower bacterial counts in the extended and post-thawed semen and better sperm motility.

\section{Viability and sperm plasma membrane integrity:}

According to the results presented in Tables ( 2 and 3 ), the presence of $7 \%$ soybean milk in extender had the best protective effect to sperm cells that was shown in the highest live spermatozoa and sperm membrane integrity compared to the all extenders used with the time of storage. Post extension viability and sperm membrane integrity didn't differ among extenders containing soybean milk and control TEY extender at $0 \mathrm{~h}$ of storage. Whereas, after $24 \mathrm{~h}$ till $96 \mathrm{~h}$, the percentages of sperm viability and plasma membrane integrity were significantly higher $(\mathrm{P}<$ $0.05) \mathrm{i}$ in $7 \%$ soybean milk extender in compared with that of the control and all other soybean milk extenders. On the other hand, the percentage of sperm viability was significantly $(\mathrm{P}<0.05)$ decreased in $13 \%$ soybean milk extender with the advancement of storage periods compared to the control TEY. Also, the percentage of sperm plasma membrane integrity in $13 \%$ soybean milk extender showed slightly lower percentage than that in control TEY extender but differences were not significant at all storage periods at $5^{\circ} \mathrm{C}$. In contrast, Singh et al. (2012) found that the percentage of viability and plasma membrane integrity of spermatozoa did not show any significant differences among extenders after 0,24 and $48 \mathrm{~h}$ of dilution, but after $72 \mathrm{~h}$ of storage, sperm viability and membrane integrity were significantly $(\mathrm{P}<0.05)$ decreased in extender with 10,15 , and $20 \%$ soybean milk compared with $25 \%$, $30 \%$ soybean milk extenders and the control. On the other hand, El Keraby et al. (2013) found that the highest $(\mathrm{P}<0.05)$ recovery rate of live spermatozoa was recorded for 7 and $10 \%$ soybean milk extenders. As soy-lecithin-based extender is superior to egg yolk based extender for bovine and ram semen (Aires et al., 2003), Akhter et al. (2011) reported that the viability of buffalo spermatozoa stored at $5^{\circ} \mathrm{C}$ was better for the semen diluted in soybean lecithin based extender compared to that diluted in milk, tris-cetric egg yolk and egg yolk citrate extenders. Moreover, de Paz et al. (2010) also suggested that lecithin soybean extender is equally effective in preserving the motility and viability of liquid ram sperm at 15 and $5^{\circ} \mathrm{C}$ as an egg yolk extender. While, Zhang et al. (2009) found that the enhanced improvement of sperm parameters in soybean added extender is due to its low viscosity and less debris. In addition, in presence of the soybean milk in extender, the phospholipids of sperm membrane may be replaced which maintain its structure and function (Trimeche et al., 1997). Another hypothesis suggested that phospholipids from soybean may integrate with sperm membrane to form a protective film against the lethal factors (Zhang et al., 2009).

Table 1. Effect of soybean milk-based extender on sperm progressive motility of bull semen cooled at $5^{\circ} \mathrm{C}$

\begin{tabular}{cccccc}
\hline \multirow{2}{*}{ Storage Periods (h.) } & \multicolumn{2}{c}{ Control } & \multicolumn{2}{c}{ Soybean milk concentrations (\%) } \\
\cline { 2 - 6 } & TEY* & $\mathbf{4 \%}$ & $\mathbf{7 \%}$ & $\mathbf{1 0 \%}$ & $\mathbf{1 3 \%}$ \\
\hline 0 & $75.4 \pm 2.2$ & $76.7 \pm 1.3$ & $77.9 \pm 1.3$ & $77.5 \pm 1.2$ & $75.8 \pm 1.8$ \\
24 & $65.4^{\mathrm{Ab}} \pm 1.3$ & $65.0^{\mathrm{Ab}} \pm 1.2$ & $68.8^{\mathrm{Aa}} \pm 1.0$ & $65.4^{\mathrm{Ab}} \pm 1.3$ & $61.3^{\mathrm{Ac}} \pm 1.1$ \\
48 & $52.9^{\mathrm{Bc}} \pm 1.7$ & $54.6^{\mathrm{Bbc}} \pm 1.3$ & $60.4^{\mathrm{Ba}} \pm 1.0$ & $56.3^{\mathrm{Bb}} \pm 1.3$ & $49.2^{\mathrm{Bd}} \pm 1.2$ \\
72 & $44.2^{\mathrm{Ccd}} \pm 1.2$ & $47.1^{\mathrm{Cbc}} \pm 1.1$ & $54.6^{\mathrm{BCa}} \pm 1.0$ & $47.9^{\mathrm{Cb}} \pm 1.1$ & $41.3^{\mathrm{Cd}} \pm 1.0$ \\
96 & $38.3^{\mathrm{Dc}} \pm 1.3$ & $41.3^{\mathrm{CDbc}} \pm 1.0$ & $49.2^{\mathrm{CDa}} \pm 1.0$ & $41.7^{\mathrm{CDb}} \pm 1.1$ & $33.8^{\mathrm{Dd}} \pm 1.3$ \\
* Rate of change (\%) & 49.2 & 46.2 & 36.8 & 46.2 & 55.4 \\
\hline
\end{tabular}

TEY $^{*}$ : Tris - Egg yolk based extender.

a,b,c,d;, , B,C,D Means with the different superscripts in the same row and column are significantly different $(\mathrm{P}<0.05)$, respectively.

$*$ Rate of change $=$ sperm progressive motility $(\%)$ at 0 time - sperm progressive motility $(\%)$ at $96 \mathrm{~h}$ of storage $/$ sperm progressive motility (\%) at 0 time of storage for each treatment.

Table 2. Effect of soybean milk- based extender on live sperm of bull semen cooled at $5^{\circ} \mathrm{C}$

\begin{tabular}{cccccc}
\hline \multirow{2}{*}{ Storage Periods (h.) } & \multicolumn{2}{c}{ Control } & \multicolumn{3}{c}{ Soybean milk concentrations (\%) } \\
\cline { 2 - 6 } & TEY* & $\mathbf{4 \%}$ & $\mathbf{7 \%}$ & $\mathbf{1 0 \%}$ & $\mathbf{1 3 \%}$ \\
\hline 0 & $79.3 \pm 2.5$ & $81.8 \pm 1.6$ & $83.8 \pm 1.0$ & $82.5 \pm 1.1$ & $81.2 \pm 1.9$ \\
24 & $72.3^{\mathrm{Ab}} \pm 1.3$ & $73.7^{\mathrm{Ab}} \pm 1.1$ & $78.8^{\mathrm{Aa}} \pm 1.0$ & $72.0^{\mathrm{Ab}} \pm 1.3$ & $68.7^{\mathrm{Ac}} \pm 1.3$ \\
48 & $60.8^{\mathrm{Bb}} \pm 1.6$ & $62.8^{\mathrm{Bb}} \pm 1.3$ & $70.3^{\mathrm{Ba}} \pm 1.0$ & $63.4^{\mathrm{Bb}} \pm 1.2$ & $56.8^{\mathrm{Bc}} \pm 1.0$ \\
72 & $52.4^{\mathrm{Cc}} \pm 1.3$ & $56.0^{\mathrm{Cb}} \pm 1.0$ & $62.6^{\mathrm{Ca}} \pm 1.2$ & $55.8^{\mathrm{Cb}} \pm 1.1$ & $49.2^{\mathrm{Cd}} \pm 1.0$ \\
96 & $46.8^{\mathrm{CDb}} \pm 1.1$ & $49.3^{\mathrm{Db}} \pm 1.0$ & $58.6^{\mathrm{CDa}} \pm 1.0$ & $48.8^{\mathrm{Db}} \pm 1.1$ & $43.0^{\mathrm{Dc}} \pm 1.0$ \\
* Rate of change (\%) $^{4}$ & 41.0 & 39.7 & 30.0 & 40.8 & 47.0 \\
\hline
\end{tabular}

$\mathrm{TEY}^{*}$ : Tris - Egg yolk based extender.

a,b,c; A,B,C,D,Means with the different superscripts in the same row and column are significantly different $(\mathrm{P}<0.05)$, respectively.

$*$ Rate of change $=$ live sperm $(\%)$ at 0 time - live sperm $(\%)$ at $96 \mathrm{~h}$ of storage $/$ live sperm (\%) at 0 time of storage for each treatment. 
Table 3. Effect of soybean milk-based extender on bull sperm membrane integrity cooled at $5^{\circ} \mathrm{C}$

\begin{tabular}{cccccc}
\hline \multirow{2}{*}{ Storage Periods (h.) } & \multicolumn{2}{c}{ Control } & \multicolumn{2}{c}{ Soybean milk concentrations (\%) } \\
\cline { 2 - 6 } & \multicolumn{1}{c}{ TEY* } & $\mathbf{4 \%}$ & $\mathbf{7 \%}$ & $\mathbf{1 0 \%}$ & $\mathbf{1 3 \%}$ \\
\hline 0 & $81.3 \pm 2.9$ & $84.9 \pm 1.7$ & $86.7 \pm 1.2$ & $85.3 \pm 1.3$ & $84.3 \pm 2.2$ \\
24 & $74.6^{\mathrm{Abc}} \pm 1.4$ & $77.7^{\mathrm{Aab}} \pm 1.6$ & $81.6^{\mathrm{Aa}} \pm 1.9$ & $73.8^{\mathrm{Abc}} \pm 2.3$ & $71.7^{\mathrm{Ac}} \pm 1.9$ \\
48 & $66.0^{\mathrm{Bbc}} \pm 2.0$ & $68.4^{\mathrm{Bb}} \pm 1.9$ & $73.8^{\mathrm{Ba}} \pm 1.5$ & $66.8^{\mathrm{Bb}} \pm 1.8$ & $61.3^{\mathrm{Bc}} \pm 1.8$ \\
72 & $58.2^{\mathrm{Cbc}} \pm 2.2$ & $60.8^{\mathrm{Cb}} \pm 1.8$ & $67.1^{\mathrm{BCa}} \pm 2$ & $59.8^{\mathrm{Cbc}} \pm 1.8$ & $54.5^{\mathrm{Cc}} \pm 1.8$ \\
96 & $52.0^{\mathrm{CDbc}} \pm 2.0$ & $55.0^{\mathrm{Db}} \pm 1.0$ & $62.5^{\mathrm{CDa}} \pm 1.8$ & $53.3^{\mathrm{Dbc}} \pm 1.1$ & $47.8^{\mathrm{Dc}} \pm 2.2$ \\
$*_{\text {Rate of change (\%) }}^{36.0}$ & 35.2 & 27.9 & 37.5 & 43.2 \\
\hline
\end{tabular}

$\mathrm{TEY}^{*}$ : Tris - Egg yolk based extender.

a,b,c; A,B,C,D Means with the different superscripts in the same row and column are significantly different $(\mathrm{P}<0.05)$, respectively.

*Rate of change $=$ sperm membrane integrity $(\%)$ at 0 time - sperm membrane integrity $(\%)$ at $96 \mathrm{~h}$ of storage / sperm membrane integrity $(\%)$ at 0 time of storage for each treatment.

Table 4. Effect of soybean milk- based extender on acrosome integrity of bull semen cooled at $5^{\circ} \mathrm{C}$.

\begin{tabular}{cccccc}
\hline \multirow{2}{*}{ Storage Periods (h.) } & \multicolumn{2}{c}{ Control } & \multicolumn{3}{c}{ Soybean milk concentrations (\%) } \\
\cline { 2 - 6 } & TEY* & $\mathbf{4 \%}$ & $\mathbf{7 \%}$ & $\mathbf{1 0 \%}$ & $\mathbf{1 3 \%}$ \\
\hline 0 & $83.5 \pm 2.4$ & $84.7 \pm 1.3$ & $87.5 \pm 1.0$ & $86.0 \pm 1.0$ & $84.4 \pm 1.9$ \\
24 & $74.5^{\mathrm{Abc}} \pm 1.0$ & $77.3^{\mathrm{Ab}} \pm 1.2$ & $82.4^{\mathrm{Aa}} \pm 1.3$ & $74.4^{\mathrm{Abc}} \pm 1.3$ & $71.9^{\mathrm{Ac}} \pm 1.6$ \\
48 & $64.8^{\mathrm{Bb}} \pm 1.8$ & $67.6^{\mathrm{Bb}} \pm 1.3$ & $73.4^{\mathrm{Ba}} \pm 1.2$ & $65.9^{\mathrm{Bb}} \pm 1.6$ & $60.3^{\mathrm{Bc}} \pm 1.4$ \\
72 & $57.8^{\mathrm{Cbc}} \pm 2.0$ & $59.5^{\mathrm{Cb}} \pm 1.3$ & $66.7^{\mathrm{Ca}} \pm 1.6$ & $59.7^{\mathrm{BCb}} \pm 1.4$ & $54.4^{\mathrm{BCc}} \pm 1.2$ \\
96 & $52.0^{\mathrm{CDb}} \pm 1.57$ & $54.5^{\mathrm{CDb}} \pm 1.3$ & $62.1^{\mathrm{CDa}} \pm 1.3$ & $52.7^{\mathrm{Db}} \pm 1.3$ & $47.8^{\mathrm{Dc}} \pm 1.3$ \\
Rate of change (\%) & 37.3 & 35.7 & 29.0 & 38.7 & 43.4 \\
\hline
\end{tabular}

$\mathrm{TEY}^{*}$ : Tris - Egg yolk based extender.

a,b,c; A,B,C,D Means with the different superscripts in the same row and column, are significantly different $(\mathrm{P}<0.05)$, respectively.

Rate of change $=$ acrosome integrity of sperm (\%) at 0 time - acrosome integrity of sperm (\%) at $96 \mathrm{~h}$ of storage / acrosome integrity of sperm (\%) at 0 time of stotage for each treatment.

\section{Acrosome Integrity of spermatozoa:}

The percentages of bull sperm acrosome integrity diluted with concentration gradients of soybean milk at levels $0,4,7,10$ and $13 \%$ during the different storage periods at $5^{\circ} \mathrm{C}$ was assessed and the results are presented in Table (4). The differences in the percentages of acrosome integrity of spermatozoa after immediate dilution were not statistically significant for all extender used $(\mathrm{P}>0.05)$. While, the percentage of acrosome integrity of spermatozoa in $7 \%$ soybean milk extender showed superior $(\mathrm{P}<$ $0.05)$ to that diluted in TEY and all other soybean milk extenders after $24 \mathrm{~h}$ till $96 \mathrm{~h}$ of storage at $5^{\circ} \mathrm{C}$. Moreover, the acrosome integrity of spermatozoa also showed higher percentages in extenders with 4 and $10 \%$ soybean milk compared to the control TEY extender but differences were not significant. Meanwhile, the acrosome integrity of spermatozoa in $13 \%$ soybean milk extender showed slightly lower than that diluted in the control TEY extender but no significant differences were observed. The present findings are supported by that of Singh et al. (2012) and El-Seify (2014) who reported that soybean contain large proportion of low-density lipoprotein called soya lecithin similar to egg yolk lecithin indicating its membrane protecting potential. This was evident after storage of bovine bull semen at $5^{\circ} \mathrm{C}$ for $96 \mathrm{~h}$ which demonstrated that replacement of egg yolk with soybean milk-based extender does not show any significant decline in evaluated parameters. According to the World Organization for Animal Health (2003), the semen processing compound should be free of any biological risk (Marco Jem-Nez et al. 2004). Soybean milk is a non-animal origin derived from plant source and considered free from any risk of contamination. Therefore, the present results show a positive effect of soybean milk based extender especially at level of $7 \%$ on semen liquid preservation. Otherwise, the high soybean milk concentration (13\%) in semen extender led to a fall in all evaluated semen parameters with the advancement of storage period. As explained by the finding of Forouzanfar et al. (2010), fall in sperm motility is possibly due to the presence of a higher concentration of soybean lecithin in the extender. Along with this, higher soybean milk concentration in semen diluents was also responsible for low viability as more lipid globules were observed in it. In addition, Hiria et al. (1997) suggested that the reduction in sperm velocity at higher soy lecithin concentration is likely due to high viscosity.

Chilling semen to low temperature is less harmful to the integrity of sperm than freezing and thawing which caused greater damage to the sperm (Singh et al., 2012). Moreover, chilling semen to $5^{\circ} \mathrm{C}$ causes just acrosome swelling, whereas, freezing and thawing causes rupture of the outer acrosomal membrane and loss of acrosome contents (Jones and 
Stewart, 1979). Chilling causes lowering of metabolic rate of spermatozoa thus extend cell viability (Vishwanath and Shannon, 2000). The most obvious advantage of liquid stored semen over cryopreserved semen is the sperm number. During cryopreservation 15-20 million spermatozoa per straw are used, whereas for liquid preservation dose rate is just one million spermatozoa per insemination (Vishwanath and Shannon, 2000) and if semen utilization is high within the shelf-life period after dilution, the economic advantages are quite significant (Curson et al., 1991).

\section{CONCLUSION}

The present results indicated that the use of $7 \%$ soybean milk in semen extender produced comparable results in comparison with the egg yolk based extender and can be used safely as a free medium from any biological risk for semen preservation to maintain cryopreserved semen quality.

\section{REFERENCES}

Aires, V.A., K.D. Hinsch, F.M. Schloesser, K. Bognera and I. Schloesser, 2003. In vitro and in vivo comparison of egg yolk-based and soybean lecithin-based extenders for cryopreservation of bovine semen. Theriogenology, 60: 269-279.

Akhter, S., M.S. Ansari, S.M.H. Andrabi, B.A. Rakha, N. Ullah, S.M.H. Andrabi and M. Khalid, 2011. In vitro evaluation of liquid-stored buffalo semen at $5 \mathrm{c}$ diluted in soybean lecithin based extender (Bioxcell), tris-citric egg yolk, skim milk and egg yolk-citrate extenders. Reprod. Dom. Anim., 46: 45-49.

Akhter, S., M.S. Ansari, S.M.H. Andrabi, B.A. Rakha, N. Ullah and M. Khalid, 2012. Soyalecithin in extender improves the freezability and fertility of buffalo (Bubalus bubalus) bull spermatozoa. . Reprod. Dom. Anim., 47: 515-519.

Ansari, M.S., B.A. Rakha, N. Ullah, S.M.H. Andrabi and S. Akhtar, 2013. Glutathion addition in Triscitric egg yolk extender improves the quality of cooled buffalo (Bubalus bubalus) bull semen. Pakistan J. Zool., 43: 49-55.

Curson, B., P. Shannon, R. Vshwanath and L.J. Burton, 1991. Recent developments in bovine liquid semen technology. In Proceedings of 4th Annual Meeting of Australian Artificial Breeders, Sydney, pp. 29-35.

de Paz, P., M.C. Esteso, L M. Alvarez, M. Mata, C.A. Chamorro and L. Anel, 2010. Development of extender based on soybean lecithin for its application in liquid ram semen. Theriogenology, 74: 663-671.

El-Keraby, F.E., K.T. Osman, H.B. Ganah and E.M. El-Siefy, 2010. Soy milk-based extender for cryopreservation of bovine semen. J. Animal and Poultry production, 1(2): 61-69.
El-Keraby, F.E., E.M. El-Siefy and M.A. Hussein, 2013. Soybean milk-based extender for cryopreservation of Egyptian buffalo semen. In Proceedings of $4^{\text {th }}$ scientific conference of Animal production Research Institute, pp. 27-32.

El-Seify, E.M., 2014. Effect of Addition different levels of soybean milk to tris diluent on the freezability and fertility of Holstein bull semen. Kafrelsheikh Vet. Med. J., 12 (2): 225-243.

Forouzanfar, M., M. Sharafi, S.M. Hosseini, S. Ostadhosseini, M. Hajian, L. Hosseini, P. Abedi, N. Nili, H.R. Rahmani and Nasr-Esfahani, 2010. In vitro comparison of egg yolk-based and soybean lecithin-based extenders for cryopreservation of ram semen. Theriogenology, 73: 480-487.

Hinsch, E., A.A. Ponce, W. Hägele, F. Hedrich, F. Muller-Schlosser and W.B. Schill, 1997. A new combined in vitro test model for the identification of substances affecting essential sperm functions. Human Reproduction, 12: 1677-1681.

Hiria, M., W.A. Cerbito, M.P.B. Wijayagunawardane, J. Braun, W. Leidl, K. Ohosaki, T. Matsuzawa, K. Miyazawa and K. Sato, 1997. The effect of viscosity of semen diluents on motility of bull spermatozoa. Theriogenology, 47: 1463-1478.

Lodhi, L.A., M. Zubair, Z.I. Qureshi, I. Ahmed and H. Jamil, 2008. Correlation between hypoosmotic swelling test and various conventional semen evaluation parameters in fresh Nili-Ravi buffalo and Sahiwal cow bull semen. Pakistan Veterinary Journal, 28: 186-188.

Jeyendran, R.S., H.H. Van Der Ven, M. PerezPelaez, B.G. Crabo and L.J.D. Zaneveled, 1984. Development of an assay to assess the functional integrity of the human sperm membrane and its relationship to other semen characteristics. J. Reprod. \& Fertility, 70: 219-228.

Jones, R.C. and D.L. Stewart, 1979. The effects of cooling to $5^{\circ} \mathrm{C}$ and freezing-thawing on the structure of bull spermatozoa. J. Reprod. \& Fertility, 56: 233-238.

Marco- Jimé, Nez F., S. Puchades, E. Mocé, M.P. Viudes-de-Cartro, J.S. Vicente and M. Rodriguez, 2004. Use of powdered egg yolk vs fresh egg yolk for the cryopreservation of ovine semen. Reprod. Dom. Anim., 39: 438-441.

Rehman, F.U., M.S. Qureshi and R.U. Khan, 2014. Effect of soybean based extenders on sperm parameters of Holstein Friesian bull during liquid storage at $4^{\circ} \mathrm{C}$. Pakistan J Zool., 46: 185-189.

SAS, Institute, 1999. Statistical Analysis System SAS, User's Guide Statistics. SAS Institute Inc., Cary, NC, USA.

Snedecor, G.W. and G.W. Cochran, 1982. Statistical Methods. $7^{\text {th }}$ Ed. The Iowa state Univ. Press Iowa, Ames., USA.

Singh, A.K., V.K. Singh, B.M. Narwade, T.K. Mohanty and S.K. Atreja, 2012. Comparative quality assessment of buffalo (Bubalus bubalis) semen chilled $\left(5^{\circ} \mathrm{C}\right)$ in egg yolk- and soybean 
milk-based extenders. Reprod. Dom. Anim., 47: 590-600.

Stradaioli, G., T. Noro, L. Sylla and M. Monaci, 2007. Decrease in glutathione (GSH) content in bovine sperm after cryopreservation between two extenders. Anim. Reprod. Sci., 67: 1249-1255.

Trimeche, A., M. Anton, P. Renard, G Gandemer and D. Tainturier, 1997. Quail egg yolk: A novel cryoprotectant for the freeze preservation of Poitou Jackass sperm. Cryobiology, 34: 385-393.

Vishwanath, R. and P.S. Shannon, 2000. Storage of bovine semen in liquid and frozen state. Anim. Reprod. Science, 62: 23-53.
Wall, R.J. and R.H. Foote, 1999. Fertility of bull sperm frozen and stored in clarified egg yolk-Tris glycerol extender. J. Dairy Sci., 82: 817-821

Younis, M., H.A. Samad, N. Ahmad and I. Ahmad, 1999. Fertility of frozen thawed semen collected from young, adult and old buffalo bulls during the low and the peak breeding seasons. Pakistan Vet. J., 19: 78-80.

Zhang, S.S., J.H. Hu, Q.W. Li, Z.L. Jiang and Z. Xiaoying, 2009. The croyoprotective effects of soybean lecithin on boar spermatozoa quality. African Journal of Biotechnology, 8: 6476-6480.

\footnotetext{
إستخدام مخفف لبن فول الصويا في حفظ السائل المنوي لطلائق الهولثتين بالتبريد علي درجة حرارة همم الثناوي محمد الصيفي' ، إبراهيم محمود عبدالرازق ' ، إبراهيم سعد الثماع

ا ـ معهد بحوث الإنتاج الحيواني، مركز البحوث الزراعية، وزارة الزراعة، الدقي، ج قسم الإتتاج الحيواني، كلية الزراعة، جامعة كفر الشيخ

تستخدم مخفقات صفار البيض منذ زمن بعيد في حفظ السائل الهنوي لطلائق الأبقار بالتجميد و التبريد. في الآونة الأخيرة ، قد أظهرت العديد

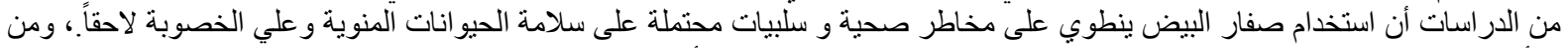

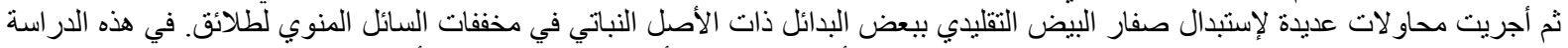

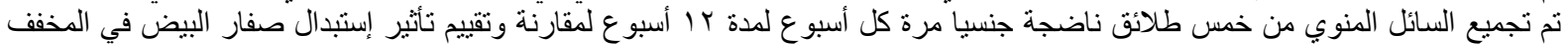

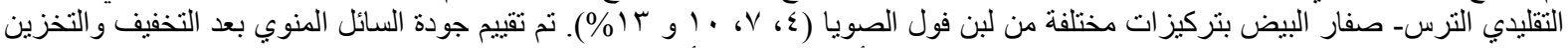

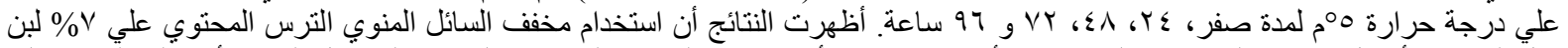

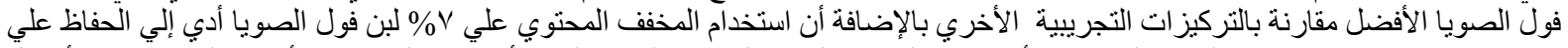

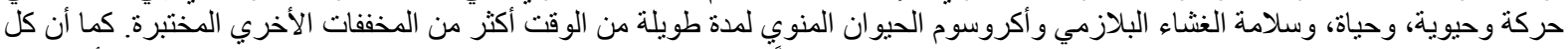

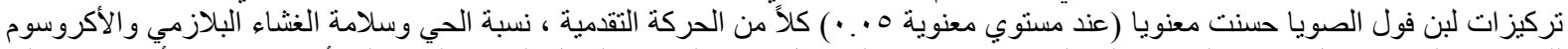

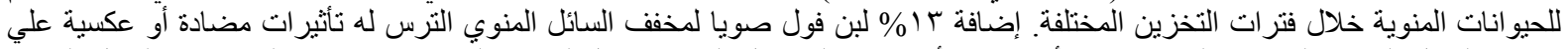

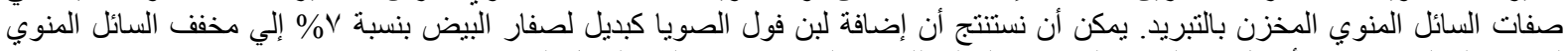

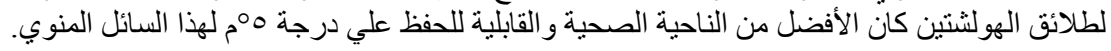

